\title{
PRAKTIK PEMBATASAN PEMBALIKAN BEBAN PEMBUKTIAN DALAM PENGADILAN TIPIKOR \\ (STUDI PADA PERKARA KORUPSI RAPBD KOTA SEMARANG DI PENGADILAN TIPIKOR KOTA SEMARANG)
}

\author{
Mulyanto \\ Kepol. Boyolali \\ Mulyantyanto189@gmail.com
}

\begin{abstract}
$R$ eversal of the burden of proof in corruption has been in effect since 1960, then entered the positive law in 1971, 1999 in conjunction with Law No. 20/2001. Inverted authentication system, in principle facilitate the country to facilitate the country's pursuit of treasure that has become the property of the individual. Because the State through the prosecution need not prove the existence of a treasure that indicated corruption, but the defendant himself who emlakukan pembukitan. But in this inverted authentication system contains a weakness because it can not be implemented at all the corruption offense. Reverse authentication occurs only in corruption offense that proved detrimental to the state finance. In the case of corruption in Semarang Corruption, Bribery case is evident is that no financial harm the state, ultimately reversed burden of proof was not done.
\end{abstract}

Keywords: Reversal of burden of proof, corruption, loss of state money.

\begin{abstract}
Abstrak
$P$ embalikan beban pembuktian dalam tindak pidana korupsi sudah berlaku sejak tahun 1960, kemudian masuk dalam hukum positif pada tahun 1971, 1999 jo UU Nomor 20/2001. Sistem pembuktian terbalik, pada prinsipnya memudahkan negara untuk memudahkan negara untuk mengejar harta yang telah menjadi milik individu. Karena Negara lewat Jaksa penuntut tidak perlu membuktikan adanya harta yang terindikasi korupsi, namun terdakwa sendirilah yang emlakukan pembukitan. Namun pada Sistem pembuktian terbalik ini mengandung kelemahan karena tidak bisa dilaksanakan pada semua delik korupsi. Pembuktian terbalik hanya terjadi pada delik korupsi yang terbukti merugikan keuangan negara. Pada perkara Korupsi di Tipikor Semarang, perkara yang terbukti adalah Suap yang tidak merugikan keuangan Negara, pada akhirnya pembuktian terbalik tidak dilakukan.
\end{abstract}

Kata kunci : Pembalikan beban pembuktian, tindak pidana korupsi, kerugian uang negara.

\section{Pendahuluan}

\section{Latar belakang}

Negara hukum merupakan cita cita sekaligus prisnip dalam penyelenggaraan praktik bernegara. Penegakan hukum merupakan salah sau indicator tercapainya penegakan hukum. Lingkaran Survey Indonesia (LSI) dan Indonesia Network Elektion Survey (INES) pernah menurunkan laporan perihal persepsi atau pandangan masyarakat terhadap penegakan hukum di Indonesia. Dalam data yang dirilis tersebut, LSI mencatat $46,7 \%$ responden tidak percaya pada hakim bisa bertindak adil dalam penegakan hukum. fakta lain yang ditemukan adalah $72 \%$ masyarakat tidak puas terhadap penegakan hukum pada masa Susilo Bambang. Menurt INES, 
hal tersebut penegakan hukum lebih banyak dilakukan intervensi oleh kepentingan pribadi dan kelompok. ${ }^{1}$

Beban pembuktian merupakan fase penting dalam penyelengaraan peradilan yang merupakan unsur penting penegakan hukum. Terkait tujuan pembuktian, para ahli berbeda pendapat dalam soal pembuktian, apakah pembuktian merupakan kewajiban bagi para pihak untuk keadilan, ataudemi sebuah kemerdekaan. Apabila bertujuan menjadi kewajiban, maka untuk tujuan kewajiban, maka hal ini hanya merujuk kepada undang-undang berlaku tentang siapa yang akan membuktikan. Namun jika pembuktian dimaknai sebagai hak, maka para pihak yang terikat dalam perkara diberikan kebebasan untuk membuktikan atau tidak membuktikan.

Makna pembuktian sebagai hak rakyat atau pihak yang berperkara, salah satunya adalah Pembalikan beban pembuktian. Pembalikan beban. Pembuktian terbalik memberikan keleluasaan bagi tersangka melakukan pembelaan dirinya dengan cara membuktikan dirinya tidak bersalah. Sungguhpun begitu, pembuktian terbalik diberlakukan secara sangat terbatas, pada perkaraperkara tertentu, yaitu perkara korupsi dalam delik grativikasi ${ }^{2}$. Pada pasal 37, Undang-Undang Nomor 31 Tahun 1999, sebagaimana telah diubah dalam undang-undang nomor 20 tahun 2001, menjelaskan bahwa pembuktian terbalik bersifat terbatas atau berimbang.

Ada dua objek yang harus dibuktikan oleh terdakwa dalam penerapan pembalikan beban pembuktian yaitu :

a. Pada tindak pidana Korupsi jenis suap yang nilainya Rp 10 juta atau lebih. ${ }^{3}$

b. Khusus pada harta benda terdakwa yang belum masuk dalam wilaya dakwaan. ${ }^{4}$

Yahya Harahap mengungkapkan pembalikan beban ayng dibatasi pada dasarnya sama dengan membuka ruang bagi totalitarianism, yang mana penguasa memilliki dikotomi dalam penilaiain tentang kebenarn. Pembuktian terbalik mewajibkan penegak hukum dalam hal ini adalah Jaksa Penuntut Umum memberikan argumentasi atas dasar serta alasan pendahuluan yang dibebankan kepada tersangka. Ditinjau dari segi hukum acara pidana, penutut umum bertindak sebagai aparat yang diberi wewenang untuk mengajukan segala daya upaya membuktikan kesalahan yang didakwakan kepada terdakwa. ${ }^{5}$

Pembalikan pembuktian bukanya tidak menyimpan sebuah dilema. Terutama jika secara cermat memperhatikan Pada ketentuan Pasal 12B dan Pasal 37, Pasal 38B UU Nomor 31 Tahun 1999 jo UU Nomor 20 Tahun 2001 Hal ini antara lain adala. Pertama, perumusan tindak pidana (materiele feit) dalam ketentuan tersebut menimbulkan kesalahan dan ketidak jelasan norma asas beban pembuktian terbalik. Kedua, merujuk kepada Konvensi PBB Anti Korupsi 2003 (KAK 2003) yang diratifikasi Indonesia dengan UU Nomor 7 Tahun 2006. ${ }^{6}$ Hakikatnya, dari beban pembuktian terbalik tersebut dilarang terhadap kesalahan orang, karena potensial akan melanggar Hak Asasi Manusia (HAM).

Ketiga, pembuktian terbalik bersimpangan dengan ketentuan hukum acara pidana dalam pasal Pasal 66 KUHAP, Pasal 66 ayat (1), (2) yang mensyaratkan terdakwa tidak dibebankan kewajiban. Keempat, Pembuktian terbalik hanya terjadi pada Delik Gratifikasi. Mestinya, terdapat sejumlah delik dalam tindak pidana korupsi yang dilakukan dengan pembuktian

1 http://www.academia.edu/6234004/Indonesia Negara Hukum. Diakses pada tanggal 3 mei 2015 : Praktek penegakan hukum di masa Presiden Susilo Joko WIdodo tidak jauh berbeda,kualitas kepercayaan public semakin menurun dengan adanya kriminalisasi KPK. Secara politik urutan kejadian tersebut menguburkan kembali optimism public yang menguat karena hukuman mati terhadap terpidana narkoba.

$2 \quad$ Pasal 37 Undang-Undang Nomor 31 Tahun 1999 tentang Pemberantasan Tindak Pidana Korupsi

3 Lihat: Pasal 12B ayat 1 Jo.pasal 37 ayat (2) jo. Pasal 38A.

4 Lihat: pasal 38B Jo. Pasal 37.

5 M.Yahya Harahap. Pembahasan Permasalahan dan Penerapan KUHAP: Pemeriksaan Sidang Pengadilan, Banding, Kasasi , dan Peninjauan Kembali. Sinar Grafika. 2010. Hlm 48

6 Pemberantasan tindak pidana korupsiundang-undang no. 3 tahun 1971 tanggal 29 maret 1971. Pasal 6 "Setiap tersangka wajib memberi keterangan tentang seluruh hartabendanya dan harta-benda isteri/suami, anak dan setiap orang serta badan yang diketahui atau yang diduga olehnya mempunyai hubungan dengan perkara yang bersangkutan apabila diminta oleh penyidik". 
terbalik. Kelima, kerancuan praktik pembalikan beban pembuktian di Pengadilan masih rancu, karena Jaksa Penuntut Umum tidak memiliki kewenangan memberikan tuntutan atas laporan kekayaan yang diperoleh dalam proses penyelidikan.

Pada ketentuan Pasal 12B dan Pasal 37, Pasal 38B UU Nomor 31 Tahun 1999 jo UU Nomor 20 Tahun 2001 diatur tentang beban pembuktian terbalik. Penulis berpandangan bahwa diperlukan kajian mendalam secara teoritis dan praktek tentang perumusan norma tentang beban pembalikan beban pembuktian dalam ketentuan Pasal 12B UU 31/1999 yo UU 20/2001. Beberapa dilema antara lain adalah :

a. Delik korupsi dilukiskan (delict omscherjving) dalam undang-undang ini dalam Bab II, Bab III, dengan judul masing-masing . Bab II Tindak Pidana Korupsi dan Bab III Tindak Pidana lain yang berkaitan dengan tindak pidana korupsi. Bab II terdiri dari pasal 2 sampai dengan pasal 20 dan Bab III teridiri dari pasal 21 sampai pasal 24. Pelukisan dalam korupsi secara (delict met formele omscherjving) memiliki kelemahan dan sebagian kurang koherensinya. Jika ada perbuatan - perbuatan korupsi yang tidak mencakup dalam pelukisan secara formil, maka si pelaku (tersangka) tidak dapat diajukan ke muka hakim. ${ }^{7}$

b. Pembalikan beban pembuktian tidak dilakukan pada tahapan pemeriksaan oleh hakim,tersangka tidak diberikan keleluasaan untuk memberikan penjelasan melalui keterangan selama masa penyelidikan dan penyidikan. Cara ini tidak layak menurut pendekatan norma penegakan hukum, Martiman mengatakan bahwa kebenaran itu hanya bisa mengenai keadaan-keadaan tertentu pada masa lampau. Oleh karena itu kebenaran atas keadaan pada masa lampau, tidak mungkin dapat dicapai. Maka hukum acara pidana hanya akan menunjukan jalan berupa guna mendekati sebanyak mungkin persesuaian antara keyakinan hakinm dan kebenaran sejati (de materiele warrheid). ${ }^{8}$

c. Dikaji dari perspektif ketentuan sistem hukum pidana khusus dihubungkan dengan Konvensi PBB Anti Korupsi 2003 (KAK 2003) yang diratifikasi Indonesia dengan UU Nomor 7 Tahun 2006. Hakikatnya, dari beban pembuktian terbalik tersebut dilarang terhadap kesalahan orang, karena potensial akan melanggar Hak Asasi Manusia (HAM), bertentangan dengan asas praduga tidak bersalah (presumption of innocence) sehingga menimbulkan pergeseran pembuktian menjadi asas praduga bersalah (presumption of guilt) atau asas praduga korupsi (presumption of corruption).

d. Dari perspektif redaksional undang-undang sangat jelas difahami bahwa terjadi pembatasan atau pengkhususan di dalam penerapan pembuktian terbalik. Pembuktian terbalik hanya berlaku pada delik grativikasi tindak pidana korupsi. Pengkhususan tersebut lah kemudian dianggap bertolak belakang dengan nurma hukum.

Pemberantasan korupsi di Indonesia memang bukan hal yang mudah. Kendala internal terutama mencakup dua aspek, yaitu aspek regulation of legality dan sumber daya manusia. Tindak pidana korupsi tergolong sebagai sebagai suatu "seriuosness crime" maka memerlukan penanganan yang luar biasa (extra ordinary enforcement or measures). ${ }^{9}$ Merespon hal tersebut, undang-undang nomor 3 tahun 1971 mulai dikenal upaya pembalikan beban pembuktian

7 Martimin Prodjohamidjojo. Penerapan Pembuktian Terbalik Delik Korupsi ; UU Nomor 31 Tahun 1999. CV. Mandar Maju. Jakarta. 2001. Hlm. 4

$8 \quad$ Ibid - Hlm.99

9 Penelitian beberapa lembaga independan seperti Transparency Internacional Indonesia (TII) telah melakukan survey yang menunjukan Indonesia merupakan negara paling korup nomor enam di dunia dari 133 negara. Dikawasan Asia, Bangladesh dan Myanmar lebih Corp. Dibandingkan Indonesia. Nilai indeks persepsi korupsi (IPK) Indonesia ternyata lebih rendah dari pada negara negara tetangga, seperti Papua Nugini, Vietnam, Filipina, Malaysia dan Singapura. Sementara itu ditingkat dunia, negara-negara ver-IPK lebih buruk dari Indonesia merupakan negara yang sedang mengalami konflik seperti Angola, Azerbaijan, Tajikistan dan Haiti. 
(Omkering van bewijslast). Sungguhpun pemberlakuannya masih bersifat terbatas, hal tersebutlah sudah menjadi dilema dalam penegakan hukum.

a. Rumusan masalah

1) Bagaimana Hukum pembalikan beban pembuktian?

b) Bagaimana Efektivitas penerapan pembalikan beban pembuktian?

c) Bagaimana Praktik Pembatasan Pembalikan Beban Pembuktian dalam Perkara Korupsi APBD Kota Semarang Tahun 2001

\section{Pembahasan}

\section{Hukum Pembalikan Beban Pembuktian}

Aturan tentang pembalikan beban pembuktian diatur dalam dua kelompok besar. ${ }^{10}$ Pertama, kelompok perbuatan pidana versi UU Nomor 31 Tahun 1999 tentang Penyelenggaraan Negara Tanpa Korupsi Kolusi dan Nepotisme, Khususnya dalam Pasal 38B (2) UU 20 Tahun 2001. ${ }^{11}$ dan Kedua, kelompok perbuatan versi UU Nomor 20 Tahun 2001, pembuktian terbalik diatur pasal 12B (1a,b). ${ }^{12}$

Pembuktian terbalik atau pembalikan beban pembuktian dalam hukum pidana khusus korupsi berlaku sebagai kewajiban, yaitu terdapat dalam Pasal 38B "Terdakwa wajib memberikan keterangan tentang seluruh harta bendanya dan harta benda istri atau suami, anak, dan harta benda setiap orang atau korporasi yang diduga mempunyai hubungan dengan perkara yang didakwakan".

Pasal 37 ayat (1) UU Nomor 20 Tahun 2001 justru menerangkan pembalikan beban pembuktian merupakan hak terdakwa. Berbeda dengan Pasal 37 (1) dan pasal 37A, Selanjutnya Pasal 37 (2) menerangkan bahwa "Dalam hal terdakwa dapat membuktikan bahwa ia tidak melakukan tindak pidana korupsi, maka pembuktian tersebut dipergunakan oleh pengadilan sebagai dasar untuk menyatakan bahwa dakwaan tidak terbukti". Pasal ini memberi arti bahwa yang memiliki hak atas semua pembuktian adalah hakim sebagai wujud dari keadilan yang dicari oleh hukum.

Prinisp pembuktian menurut KUHAP pada prinsipnya adalah "siapa yang mendakwakan maka dialah yang dibebani untuk membuktikan apa yang didakwakan itu benar”. Prinsip ini timbul dari berlakunya asas presumption of innocence sebagai azas penting dalam Hukum Acara Pidanan. Asas ini tertuang dalam pasal 8 Undang-Undang Nomor 4 Tahun 2004 tentang Kekuasaan Kehakiman, yang menyatakan setiap orang dianggap tidak bersalah sampai kesalahannya itu dibuktikan dengan suatu putusan pengadilan yang telah mempunyai kekuatan hukum tetap.

UU Nomor 8 Tahun 1981 Tentang Hukum Acara Pidana bagian ke-empat, menegaskan segala pembahasan terkait pembuktian di dalamnya merupakan "pembuktian dan putusan dalam acara pemeriksaan biasa". Sedangkan bentuk pemeriksaan dalam pidana khusus seperti tidak pidana korupsi, tergolong pemeriksaan luar biasa. Alat bukti yang diatur dalam KUHAP Pasal 183 tetap berlaku sebagai alat bukti dalam pidana khusus.

10 Pernyataan Hakim TIPIKOR Jawa Tengah - Kalimatul Jumrah dalam wawancara pada tanggal 8 Juni 2015

11 Pasal 38 B UU Nomor 20 Tahun 2001

(1) Setiap orang yang didakwa melakukan salah satu tindak pidana korupsi sebagaimana dimaksud dalamPasal 2, Pasal 3, Pasal 4, Pasal 13, Pasal 14, Pasal 15, dan Pasal 16 Undang-undang Nomor 31 Tahun 1999 tentang Pemberantasan Tindak Pidana Korupsi dan Pasal 5 sampai dengan Pasal 12 Undang-undang ini, wajibmembuktikan sebaliknya terhadap harta benda miliknya yang belum didakwakan, tetapi juga diduga berasal dari tindak pidana korupsi.

12 UU Nomor 20 Tahun 2001 : Pasal 12 B (1) Setiap gratifikasi kepada pegawai negeri atau penyelenggara negara dianggap pemberian suap, apabila berhubungan dengan jabatannya dan yang berlawanan dengan kewajiban atau tugasnya, dengan ketentuan sebagai berikut:

a. yang nilainya $\mathrm{Rp} 10.000 .000,00$ (sepuluh juta rupiah) atau lebih, pembuktian bahwa gratifikasi tersebut bukan merupakan suap dilakukan oleh penerima gratifikasi;

b. yang nilainya kurang dari Rp 10.000.000,00 (sepuluh juta rupiah), pembuktian bahwa gratifikasi tersebut suap dilakukan oleh penuntut umum. 
Tindak Pidana Korupsi digolongkan pidana khusus, yang memberlakukan pembalikan beban pembuktian. Namun pembalikan beban pembuktian tersebut harus diperkuat dengan formula pembuktian sebagaimana diatur dalam KUHAP. Tepatnya alat bukti berupa " Keterangan Terdakwa"13 Keterangan terdakwa merupakan instrumen penerapan pembalikan beban pembuktian dalam perkara pidana khusus seperti korupsi. ${ }^{14}$

\section{Efektiivitas penerapan pembalikan beban pembuktian?}

Kesulitan mendeteksi harta negara yang sudah ada dalam kepemilikina pribadi menjadi salah satu tujuan diberlakukanya pembuktian terbalik. Untuk hal ini negara membutuhkan instrument hukum yang bisa memperkuat negara untuk mendapatkan kembali kekayaan yang hilang tersebut. Sejak diterapkan melalui UU Nomor 31 Tahun 1999, system pembalikan beban pembuktian telah memberikan pengaruh besar dalam pemberantasan tindak pidana korupsi.

Kekuatan pembuktian kekayaan negara dibebankan kepada terdakwa. Dalam embuktian terbalik, terdakwa melaporkan kekayaan secara periodik juga merupakan salah satu unsur pendukung efektivitas Pembuktian Terbalik dalam gratifikasi. Pemberlakuan pembuktian terbalik di Indonesia terbukti cukup efektif. Selama diundangkan dan diberlakukan, pembalikan beban pembuktian telah membantu hakim membuat putusan yang berdampak positif, yaitu berupa terlacaknya keberadaan kekayaan negara yang dialihkan oleh pelaku.

Komisi Pemberantasan Korupsi merasa diuntungkan dengan adanya pembuktian terbalik ini. Tercatat beberapa kasus besar bisa ditangani secara tuntas. Komisi Pemberantasan Korupsi (KPK) berhasil menyetor Penerimaan Negara Bukan Pajak (PNBP) sebesar Rp 1,196 triliun kepada negara dan pemerintah daerah. Jumlah tersebut diperoleh dari hasil penanganan perkara tindak pidana korupsi sebesar Rp 1,178 triliun dan gratifikasi Rp 18,568 miliar. KPK berhasil mengembalikan Uang negara yang berasal hasil denda, uang pengganti kerugian negara, uang sitaan hasil korupsi, serta pendapatan dari lelang barang-barang gratifikasi yang telah ditetapkan milik negara. sepanjang tahun 2013 ini. ${ }^{15}$ Berdasarkan data KPK per-tahun 2013 dari jenis kasus pidana yang ditangani sekitar $70 \%$ adalah kasus suap. ${ }^{16}$

13 KUHAP Pasal 189 : Keterangan Terdakwa

a. Keterangan terdakwa adalah apa yang terdakwa nyatakan di sidang tentang perbuatan yang ia lakukan atau yang ia ketahui sendiri atau alami sendiri ;

b. Keterangan terdakwa yang diberikan di luar sidang dapat digunakan untuk membantu penemuan bukti di sidang,asalkan keterangan itu didukung oleh satu alat bukti yang sah sepanjang mengenai hal yang didakwakan kepadanya ;

c. Keterangan terdakwa hanya dapat digunakan terhadap dirinya sendiri

d. Keterangan terdakwa saja tidak cukup untuk membuktikan bahwa ia bersalah melakukan perbuatan yang didakwakan kepadanya, melainkan harus disertai dengan alat bukti yang lain.

14 Pendapar Hakim TIPIKOR Jawa Tengah. Agus Sudjadi. Dalam Wawancara pada tanggal 17 Mei 2015

15 Dalam Catatan Akhir Tahun KPK 2013 terungkap, pendapatan terbesar berasal dari pendapatan uang pengganti tindak pidana korupsi yang ditetapkan pengadilan sebesar $\mathrm{Rp} 654,533$ miliar. Peringkat kedua ditempati pedapatan yang sitaan hasil korupsi sebesar Rp 232,195 miliar. Pendapan yang tak kalah besar juga diperoleh dari hasil denda yang mencapai Rp 36,668 miliar. Sedangkan pendapatan dari gratifikasi yang ditetapkan KPK milik negara mencapai Rp 18,568 miliar. Sementara itu, pendapatan dari penjualan hasil lelang tindak pidana korupsi mencapai Rp 12,965 miliar. Diikuti pendapatan jasa lembaga keuangan atau jasa giro sebesar Rp 12,427 miliar. "Jumlah PNBP dari hasil perkara tindak pidana korupsi tersebut yang disetor ke kas negara sebesar Rp 949,542 miliar. Sedangkan yang disetor ke kas daerah mencapai Rp 228,880 miliar," KPK Setor Rp 1,19 Triliun ke Kas Negara dan Daerah. http://kpk.go.id/id/berita/berita-sub/1595-kpk-setor-rp-1-19-triliun-ke-kas-negara-dan-daerah

16 Laporan media : Bambang Eka Wijaya http://lampost.co/berita/vonis-

a. Majelis Hakim Pengadilan Tindak Pidana Korupsi Jakarta Selasa memvonis kasus pidana pencucian uang dengan asas pembuktian terbalik, merampas untuk negara sejumlah harta Irjen Pol. Djoko Susilo yang telah disita KPK hanya dengan klausul diduga hasil korupsi 2002-2010 dan 2010-2012. (46 item, 40-an item terdiri dari tanah, dengan bangunan di atasnya berupa rumah mewah atau SPBU dengan surat-surat hak milik atas nama orang lain—di antaranya atas nama istri-istri Djoko,uang tunai Rp1 miliar lebih dan dua mobil—Mercy dan jip)

b. Majelis hakim Pengadilan Negeri (PN) Jakarta Selatan yang diketuai Didik Setyo Handono menyatakan terdakwa terbukti bersalah karena mendapat setoran Rp 1 miliar dari Kartini Mulyadi, atas keterangan terdakwa Bahasyim dalam 
Tantangan bagi Korupsi adalah canggihnya modus operandi yang terbilang sistematis lagi terorganisir. Meski terbukti efektif dalam pembukitan UU Nomor 31 Tahun 1999 dirasa kurang mampu dalam mengahapi kecanggihan startegi koruptor. UU Nomor 31 Tahun 1999 menganut sistem pembuktian yang berdasar undang-undang secara negative (negatief wettelijke bewijs theorie), pemidanaan didasarkan kepada pembuktian yang berganda yaitu pada peraturan perundangan dan pada keyakinan hakim sesuai dengan pasal 183 KUHAP yaitu 2 alat bukti yang sah dan keyakinan hakim itu sendiri. ${ }^{17}$ Dalam hal ini para Pelaku berusaha sebisa membawa alat bukti tidak lebih dari dua.

UU Nomor 20 Tahun 2001 adalah pelengkap dari UU Nomor 31 Tahun 1999 yang menganut Pembuktian Terbalik Berimbang. Dalam hal ini seorang terdakwa wajib membuktikan kekayaannya yang bukan berasal dari tindak pidana korupsi, dan hakim berdasarkan bukti-bukti yang membenarkan Terdakwa maka memutuskan ia tidak bersalah. ${ }^{18}$ Pembuktian Terbalik Berimbang ini didukung perluasan dan penambahan alat bukti yaitu informasi atau dokumen yang direkan secara elektronik (Pasal 26A).

M Akhil Mukhtar mencatat ada tiga kendala dalam penerapan Pembalikan Beban Pembuktian, yaitu Pertama ; Aspek budaya dalam masyrakat. Budaya balas jasa sudah merekat. Hal ini kadang diberikan kepada para pejabat negara, yng seharusnya tidak boleh menerima apapuns elain pemberina yang sudah ditentukan oleh negara. Prakter tersebut kerap menimbulkan manipulasi seperti yang tercantum dalam pasal 12 B UU Nomor 20 Tahun 2001. Kedua, Ketidakpaduan antara lembaga penegak hukum, yang membuat peradilan menjadi lemah. Ketiga ; pertentangan yuridis dengan berbagai alasan, seperti pembalikan beban pembuktian yang dipertentangkan dengan Hak Asasi Manusia apabila dikaitkan dengan asas "Presumption Of Innocence" atau asas praduga tak bersalah, berpotensi terjadinya Judicial Crime. ${ }^{19}$

\section{Praktik Pembatasan Pembalikan Beban Pembuktian dalam Perkara Korupsi APBD Kota Semarang Tahun 2001}

Perkara tindak pidana korupsi yang menjadi obyek adalah korupsi APBD kota Semarang. Perkara ini bermula dari adanya keinginan Walikota Semarang untuk mengubah budget Rencana Anggaran Belanja Daerah tahun 2012. Walaupun pada awalnya, masing-masing SKPD telah membuat dan mengajukan anggaran belanja tahun 2012, tetapi ada keinginan politik untuk tetap melakukan revisi terhadap budget yang telah diajukan kepada Sekretaris Daerah selaku ketua penyusunan RAPBD Kota Semarang. ${ }^{20}$

Jaksa Penuntut, di dalam dakwaannya terhadap terdakwa Ahmad Zaenuri dikelompokan menjadi dua jenis dakwaan yaitu dakwaan primair dan dakwaan subsidair, sebagai berikut :

pembuktian terbalik . Bahasyim juga tidak bisa membuktikan bahwa uang Rp 60,9 miliar dan US\$ 681.147 miliknya bukan berasal dari korupsi, majelis juga menyatakan harta itu disita untuk negara. Dalam persidangan, Bahasyim dan keluarganya terungkap memiliki rekening dengan total transaksi lebih dari Rp 1,5 triliun. Tapi yang dinyatakan sebagai harta tidak wajar milik bekas pegawai negeri golongan IV ini hanya sekitar Rp 60 miliar.

c. Pembuktian terbalik patut diterapkan dalam kasus Gayus Tambunan. Pidana suap karena Gayus telah melanggar ketentuan Pasal 12 a dan b UU Tipikor yang melarang pegawai negeri atau penyelenggara negara menerima suap yang diberikan untuk menggerakkan atau sebagai akibat telah melakukan sesuatu dalam jabatannya yang bertentangan dengan kewajibannya. Selain itu,Gayus juga dapat didakwa melakukan penyuapan kepada aparat penegak hukum, baik di kejaksaan, kepolisian, maupun pengadilan pajak.

17 A Hamzah, Hukum Acara Pidana Indonesia (Jakarta: CV. Setiawan Indah Abadi,1996), 264

18 M Akil Mochtar, Memberantas Korupsi (Jakarta: Q-Communication,2006), 87

19 M. Achil Mukhtar. Op.Cit.

20 Informasi perkara ini diketahui oleh penulis dari berbagai media masa :

a. http://kpk.go.id/id/nukpk/id/berita/berita-sub/430-sekda-kota-semarang-diganjar-1-5-tahun-penjara.

b. http://www.merdeka.com/tag/k/kasus-korupsi/penahanan-sekda-kota-semarang-dipindah-ke-lp-kedungpane.html.

c. http://nasional.tempo.co/read/news/2012/11/05/058439822/eks-sekda-semarang-resmi-jadi-koruptor ; Kesemuanya diakses pada tanggal 01 Juni 2015 
a. Dakwah Primair

AkhmatZaenuri, selaku terdakwa Memberi atau menjanjikan sesuatu berupa uang tunai sejumlah Rp.304.000.000,- (tiga ratus empat juta rupiah), dan sejumlah Rp.40.000.000,(empat puluh juta rupiah) kepada pegawai negeri atau penyelenggara negara, yaitu kepada anggota DPRD Kota Semarang. Terdakwa diduga melakukan perbuatan memberikan uang kepada para pihak sebanyak dua kali, tujuan terdakwa memberikan uang tersebut kepada DPRD adalah untuk mempengaruhi kebijakan perubahan RAPERDA 2012. Sungguhpun begitu, tujuan dari tindakan suap tersebut belum terjadi, rapat pembahasan RAPBD tidak sampai mengakomodir usulan penambahan anggaran oleh Bupati. Artinya hal tersebut tidak memenuhi unsur adanya tujuan suap yaitu "untuk berbuat atau tidak berbuat". Pasal 5 UU Nomor 20 Tahun 2001 menjelaskan tentang dua perbuatan pokok dalam korupsi yaitu :

1) Memberi atau menjanjikan sesuatu kepada pegawai negeri atau penyelenggara negara dengan maksud supaya pegawai negeri atau penyelenggara negara tersebut berbuat atau tidak berbuat sesuatu dalam jabatannya, yang bertentangan dengan kewajibannya; atau

2) Memberi sesuatu kepada pegawai negeri atau penyelenggara negara karena atau berhubungan dengan sesuatu yang bertentangan dengan kewajiban, dilakukan atau tidak dilakukan dalam jabatannya.

Namun Jaksa Penuntut Umum dalam dakwaannya menjelaskan bahwa perbuatan diduga dengan kewajibannya sebagai soerang pejabat negara. Yaitu kewajiban anggota DPRD selaku penyelenggara negara untuk tidak melakukan perbuatan korupsi, kolusi dan nepotisme sebagaimana diatur dalam Pasal 5 angka 4 Undang-undang RI Nomor 28 Tahun 1999 tentang Penyelenggaraan Negara Yang Bersih dan Bebas dari Korupsi, Kolusi dan Nepotisme. Lalu berkaitan dengan tata tertib dan kode etik sebagaimana diatur dalam pasal 30 huruf g Peraturan Dewan Perwakilan Rakyat Daerah Kota Semarang Nomor 1 tahun 2010 tentang Tata Tertib Dewan Perwakilan Rakyat Daerah Kota Semarang.

Perbuatan terdakwa tersebut diancam pidana sebagaimana diatur dalam Pasal 5 ayat (1) huruf a Undang-undang Nomor 31 tahun 1999 tentang Pemberan-tasan Tindak Pidana Korupsi sebagaimana telah diubah dengan Undang-undang Nomor 20 tahun 2001 tentang perubahan atas Undang-undang Nomor 31 tahun 1999 tentang Pemberantasan Tindak Pidana Korupsi jo Pasal 55 ayat (1) ke-1 KUHPidana jo Pasal 64 ayat (1) KUHPidana.

\section{b. Dakwaan Subsidair}

Dakwaan Subsidair yang diajukan Jaksa Penuntut adalhPasal 13 Undang-undang Nomor 31 tahun 1999 tentang Pemberantasan Tindak Pidana Korupsi sebagaimana telah diubah dengan Undang-undang Nomor 20 tahun 2001 tentang perubahan atas Undangundang Nomor 31 tahun 1999 tentang Pemberantasan Tindak Pidana Korupsi jo pasal 55 ayat (1) ke-1 KUHPidana jo pasal 64 ayat (1) KUHPidana.

Terhadap dakwaan dari Jaksa, maka terdakwa menyampaikan pembelaan (Pleidooi) yang dibacakan oleh Penasehat Hukumnya. Dalam pledooi ditegaskan bahwa : ${ }^{21}$

1) Bahwa pada dasarnya terdakwa mengakui perbuatan terdakwa memberikan uang kepada Anggota DPRD Kota Semarang dalam upaya untuk melancarkan dan memuluskan pembahasan RAPERDA APBD menjadi PERDA APBD adalah bertentangan dengan upaya pemerintah dalam upaya pemberantasan tindak pidana korupsi;

2) Bahwa terdakwa melakukan perbuatan tersebut semata-mata karena loyalitas terdakwa kepada Pimpinan, serta tidak ada kuasa untuk menolak perintah atasan, bukan karena desakan ekonomi karena kepentingan terdakwa pribadi;

21 Keterangan dan Dokumen dari Penasehat Hukum Terdakwa Lutfi Akbar, dalam wawancara pada tanggal 27 Juni 2015 di Semarang. 
3) Bahwa niat, ide, gagasan, dan kehendak melakukan perbuatan tersebut bukan berasal dan berawal dari terdakwa, tetapi dari pihak-pihak lain yaitu sebagian Anggota DPRD Kota Semarang, Atasan terdakwa, serta beberapa Kepala SKPD;

4) Bahwa dana yang dipergunakan untuk melakukan suap tidak diambil dari kas negara atau daerah, tetapi berasal dari uang milik pribadi.

Hakim berusaha melakukan pengujian terhadap saksi dan bukti, kemudian menjadikannya sebagai dasar untuk membangun keyakinan guna membuat putusan hukum yang berkukuatan adil. Dalam Perkara ini memperlihatkan secara jelas bahwa telah terjadi tindak pidana suap, tetapi tindakan tersebut tidak menyebabkan alasan bagi diberlakukannya pembalikan beban pembuktian.

Perkara ini (suap) telah terbukti terjadi praktek pemberian uang yang diduga menyebabkan dua orang anggota DPRD Kota Semarang memperkaya diri sendiri, tetapi pada dasarnya kekayaan tersebut tidak ada hubungannya dengan keuangan negara/ atau daerah. Perkara ini pada dasarnya tidak menyebabkan kerugian keuangan dan kekayaan negara / atau daerah, atau tidak pula menyebabkan negara / atau daerah kehilangan potensi pendapatan ekonomis.

Mendasarkan kepada alasan yang demikian, hakim tidak menerapkan pembalikan beban pembuktian, mengingat Hakim tidak melihat adanya urgensi perkara ini terkait mengakses uang dan kekayaan negara lalu kemudian upaya perampasan kembali ke kas negara/ atau daerah.

Pada prinsipnya semua delik dalam pidana korupsi tidak bisa diterapkan pembuktian terbalik, kecuali terhadap perbuatan tersebut terkait laingsung dengan prinsip-prinsip pembatasan dan perimbangan yang dimaksud oleh undang-undang. Adapun pembatasan tersebut mencakup hal-hal sebagai berikut : ${ }^{22}$

1) Pembuktian terbalik hanya dibatasi pada jenis perbuatan korupsi yang menyebabkan negara mengalami kerugian berupa uang atau kekayaan lain senilai Rp. 10.000.000 atau lebih besar dari nilai tersebut. Hal tersebut disebabkarena nilai di bawah Rp.10.000.000 masih sangat mudah dilakuakan pelacakan oleh negara, sebaliknya nilai di atas itu sulit dilakukan pelacakan. ${ }^{23}$

2) Pembuktian terbalik hanya dibatasi pada perbuatan korupsi yang diduga di dalamnya telah terjadi peralihan uang dan kekayaan negara kepada pihak lain secara melanggar hukum.

Maka perkara tersebut diputuskan oleh hakim sebagaimana berikut :

1) Dakwaan primair yang disampaikan oleh Penuntut umum tidak diterima. Oleh karena itu maka terdakwah dibebaskan dari dakwaan primair.

2) Sementara itu pengujian terhadap dakwaan subsidier yang dilakukan oleh hakim dalam pemeriksaan persidangan, menemukan bukti kebenaran telah terjadinya tindak pidana yang dilakukan oleh terdakwah yaitu "Turut Serta Melakukan Tindak Pidana Korupsi yang dilakukan Secara Berlanjut".

3) Adapun isi putusan hakim sebagai berikut : ${ }^{24}$

a) Menjatuhkan pidana terhadap terdakwa drs. Akhmat Zaenuri, oleh karena itu dengan pidana penjara selama 1 (satu) tahun dan 6 (enam) bulan, serta pidana denda sejumlah Rp.50.000.000,- (lima puluh juta rupiah), dengan ketentuan apabila Pidana Denda tersebut tidak dibayar, maka diganti dengan Pidana Kurungan selama 2 (dua) bulan; 
b) Menetapkan agar lamanya terdakwa berada dalam masa penangkapan dan/ atau penahanan dikurangkan seluruhnya dari pidana yang dijatuhkan;

c) Memerintahkan agar terdakwa tetap berada dalam tahanan ;

d) Memerintahkan agar Barang Bukti berupa ; ${ }^{25}$

e) Membebankan kepada Terdakwa untuk membayar biaya perkara sejumlah Rp.5.000,- (lima ribu rupiah) ;

Penulis berpendapat, Pembuktian Terbalik membuka kesempatan kepada terdakwa koruptor untuk memanipulasi sebagai jalan agar tidak terjadi pembuktian harta korupsi. Kebohongan tersebut tentunya membuat jaksa penuntut umum bekerja lebih keras untuk membenarkan dakwaanya. Adapun Jaksa harus memastikan tentang nilai uang dan kekayaan terdakwa sebelum terjadi peralihan atau aliran uang atau kekayaan negara kepadanya melalui tindak pidana korupsi.

\section{Kesimpulan}

1. Pada dasarnya pembuktian terbalik dapat diterapkan semua delik pidana korupsi baik dalam UU Nomor 31 Tahun 1999 atau UU Nomor 20 Tahun 2001. Adapun unsur unsur agar penerpan pembalikan dengan beban terbalik dapat dilakukan dengan dua hal. Pertama, adanya kerugian negara yang ditandai dengan peralihan uang atau kekayaan negara kepada terdakwa. Adapun setiap perbuatan sebagaimana dimaksud dalam UU Nomor 31 Tahun 1999 atau UU Nomor 20 Tahun 2001, yang terbukti menyebabkan kerugian uang dan kekayaan negara, dan diduga terjadi peralihan kekayaan, maka dapat diperiksa dengan pembuktian terbalik.

2. Penerapan sistem pembuktian terbalik dirasakan sangat efektif dalam menangani tindak pidana korupsi, paling tidak pembuktian tersebut untuk meminimalisir adanya kerugian negara akibat tindak pidana korupsi. Sebab pada prinsipnya tujuan dari pembuktian terbalik adalah untuk melacak keuangan negara yang dialihkan menjadi milik pribadi.

3. Perkara Korupsi yang terjadi di Pengadilan Tipikor Semarang, pada dasarnya tidak merugikan keuangan negara, karena masuk uunsur tindak pidana suap. Adapun tidak terjadinya kerugian negara dan tergolong sebagai salah satu syarat untuk dilakukanya Pembuktian terbalik, namun karena masuk perkara suap yang tidak merugikan keuangan negara, maka pembuktian terbalik dalam persidangan tidak dilakukan.

\section{Daftar Pustaka}

Hamzah, Andy Hukum Acara Pidana Indonesia (Jakarta: CV. Setiawan Indah Abadi,1996),

Harahap, M.Yahya. Pembahasan Permasalahan dan Penerapan KUHAP: Pemeriksaan Sidang Pengadilan, Banding, Kasasi , dan Peninjauan Kembali. Sinar Grafika. 2010. Hlm 48

KUHAP Pemeriksaan Sidang Pengadilan, Banding. 2006. Kasasi, dan Peninjauan Kembali: Edisi Kedua. Jakarta: Sinar Grafika.

Lopa, Baharuddin \& Moh Yamin. 1987. Undang-Undang Tindak Pidana Korupsi (UndangUndang No. 3 tahun 1971) Berikut Pembahasan serta Penerapannya Dalam Praktek, Bandung: Alumni.

Mochtar, Akil, Memberantas Korupsi (Jakarta: Q-Communication,2006),

Prodjohamidjojo, Martimin. Penerapan Pembuktian Terbalik Delik Korupsi ; UU Nomor 31 Tahun 1999. CV. Mandar Maju. Jakarta. 2001.

25118 bukti yang diajukan dalam persidangan tetap dalam status sita untuk dipergunakan dalam perkara lain. 


\section{Aturan Perundang Undanagan}

Undang-undang Dasar 1945 perubahan ke-tiga TAP MPR Rakyat Republik Indonesia Nomor XVII/ MPR/ 1998 tentang Hak Asasi Manusia.

Kitab Undang-undang Hukum Acara Pidana.

UU No.31/1999 tentang Pemberantasan Tindak Pidana Korupsi.

UU Nomor 28 Tahun 1999 tentang Penyelenggaraan Negara yang Bersih dan Bebas dari Korupsi, Kolusi, dan Nepotisme.

UU No. 39 Tahun 1999, tentang Hak Asasi Manusia.

UU No. 51 Tahun 2009. Sistem Peradilan TUN.

UU No. 30 Tahun 2002 tentang Komisi Pemberantasan Tindak Pidana Korupsi.

UU Nomor 46 Tahun 2009 tentang Pengadilan Tindak Pidana Korupsi.

UU No. 20 Tahun 2001 tentang Perubahan Atas UU Nomor 31 Tahun 1999 tentang Pemberantasan Tindak Pidana Korupsi.

\section{Media dan Jurnal}

\section{HTTP://WWW.ACADEMIA.EDU/6234004/INDONESIA_NEGARA_HUKUM}

Jurnal Legislasi Indonesia.Vol.8 No 21 Juni 2011. http:// www.djpp.depkumham.go.id./arsip/ artikel/jurnal/jild8n2.pdf. diakses pada tanggal 8 agustus 2015

Topo Santoso. Pembuktian Terbalik Hanya Pengalihan Isu : http://www.hukumonline.comdiakses pada tanggal 22 Juni 2015

T. Mulia Lubis. Pembuktian Terbalik Tidak Mudah, http://www.hukumonline.com-diakses pada tanggal 22 Juni 2015.

Dalam Catatan Akhir Tahun KPK 2013. Laporan media : Bambang Eka Wijaya http://lampost. co/berita/vonis-

http:/www.boyyendratamin.com/2012/02/pembalikan-beban-pembuktian-dalam.html.

Website KPK: http://kpk.go.id/id/nukpk/id/berita/berita-sub/430-sekda-kota-semarangdiganjar-1-5-tahun-penjara. diakses pada tanggal 22 Mei 2015.

http://kpk.go.id/id/nukpk/id/berita/berita-sub/430-sekda-kota-semarang-diganjar-1-5-tahunpenjara.

http://www.merdeka.com/tag/k/kasus-korupsi/penahanan-sekda-kota-semarang-dipindah-kelp-kedungpane.html.

http://nasional.tempo.co/read/news/2012/11/05/058439822/eks-sekda-semarang-resmi-jadikoruptor; 